\title{
Testicular and some hormonal changes during the first four years of life in the mirror carp, Cyprinus carpio $\mathrm{L}$.
}

\author{
R. Billard*, C. Weil $\dagger$, K. Bieniarz $\ddagger$, T. Mikolajczyk $\ddagger$, B. Breton $\dagger$, \\ P. EPLER $\ddagger$ AND M. BOUGOUSSA $\dagger$ \\ * Laboratory of Ichthyology, Museum National d'Histoire Naturelle, 43, rue Cuvier, \\ 7523l Paris, + Laboratory of Fish Physiology-INRA, Campus de Beaulieu, 35042 Rennes, \\ France and $\ddagger$ Faculty of Agriculture, Department of Ichthyology and Fisheries, Ambrosova 6 , \\ Krakow Midlnicki, Poland
}

(Received 9 September 1991, Accepted 9 February 1992)

\begin{abstract}
Male carp bred in outside ponds in Poland were sampled monthly from 5 to 46 months old, to analyse changes in gonadosomatic index (GSI) and pituitary gonadotropin hormone (GTH) in blood scrum and in pituitary, $17 a 20 \beta \mathrm{P}$ and $11 \mathrm{KT}$ in blood and gonadotropin releasing hormone $(\mathrm{GnRH})$ in pituitary and hypothalamus. First signs of puberty with significant testis development (a high GSI of $12 \%$ and strong mitotic activity of the type-B spermatogonia) were seen at 13 months and $4548^{\circ}$ days. By 16 months the GSI had declined to $6 \%$. At 25 months the GSI remained at $6 \%$, active spermatogenesis was observed, with some accumulation of spermatozoa but no spermiation. During the years 4 and 5 the GSI increased regularly from 6 to $12 \%$ and spermiation was observed nearly all the time. Some GTH was found in the blood before gonad development occurred. Thereafter there was no major change in GTH $\left(10-20 \mathrm{ng} \mathrm{ml}{ }^{-1}\right.$ serum $)$ except a peak of $200-130 \mathrm{ng} \mathrm{ml}^{-1}$ at 3839 months: this peak was not related to any major biological event, except that all fish reached spermiation at that time. A progressive increase of the amount of GTH in the pituitary was observed during the sampling period. Opposite fluctuations in the GnRH content were observed in brain and pituitary. Circulating 11-ketotesterone (11-KT) increased to $2030 \mathrm{ng} \mathrm{ml}^{-1}$ serum in spring 22-25 months and at 36-37 months in parallel with the progressive rise of the water temperature, but independently of stage of testes development. These peaks of 11-KT were followed immediately (1984) or two months later (1983) by temporary major rises of $17 a$-hydroxy-20 $\beta$-dihydroprogesterone reaching $2-3 \mathrm{ng} \mathrm{ml}$ ' serum; this was not related to the temperature nor to the spermatogenetic stage.
\end{abstract}

Key words: spermatogenesis; carp; 11-KT; 17a20קP; c-GTH: GnRH.

\section{INTRODUCTION}

Only limited information is available on the gonadal and related hormonal changes in the common carp, Cyprinus carpio L., during the establishment of puberty and subsequent reproductive cycles. Work by Solewski $(1957,1958)$ described the change in gonadosomatic index (GSI) in males and females during a period of nearly 3 years post-hatching. Some other work concentrated more on the reproductive cycle in older fish with the study of GSI and gametogenesis (Crivelli, 1981; Weil, 1981; Horvath, 1986), and the steroid profiles during spermiation (Barry et al., 1990a). The work by Weil (1981) included some analysis of hormonal changes during the cycle [plasma and pituitary gonadotropin hormone (GTH) content, plasma estradiol and total androgens]. Bieniarz (1986) reviewed sex differentiation and establishment of puberty in different cyprinids and indicated that the available data for this last point were very limited in carp. Therefore the present work examined the changes occurring after sex differentiation, in the development of the 
testes in relation to hormonal changes. The hormones measured were pituitary and plasma gonadotropin, plasma steroids such as 11 -ketotesterone (11-KT) and $17 a$-hydroxy-20 $\beta$-dihydroprogesterone $(17 a 20 \beta \mathrm{P})$, and gonadotropin releasing hormone (s-GnRH) present in the pituitary and the hypothalamus. Similar work on females has been reported in another paper (Bieniarz et al., 1991).

\section{MATERIAL AND METHODS}

In this experiment about 500 male carp were used, originating from one pair of spawners. Spawning took place at the end of May 1981. Observations lasted from October 1981 (5 months of age) until March 1985 (46 months of age). Males and females were kept together in typical earth ponds. They were fed ad libitum with carp pellets, made locally $(25 \%$ protein). Ten to 20 males were sampled at intervals of a few months from October 1981 to March 1983, and every month thereafter. The water temperature was taken daily in the ponds.

Blood samples were taken around $5 \mathrm{~h}$ after sunrise. After killing, gonads (from October 1981), hypothalami (from June 1984) and pituitaries (from October 1981) were collected. Blood serum was preserved with merthiolate and kept at $-20^{\circ} \mathrm{C}$, as well as the hypothalami and pituitaries, until the measurement of serum and pituitary GTH by radioimmunological assay (RIA), all made at the end of the sampling period (Breton et al., 1971). Before the assay, pituitaries and hypothalami had been homogenized in $0.1 \mathrm{~N}$ acetic acid in the case of s-GnRH measurement by RIA (Breton et al., 1986). An aliquot was incubated (vol. 1:1) with phosphate buffer $(\mathrm{pH} 8)$ in order to reach $\mathrm{pH} 7$ and reassociate the GTH subunits for further determination of GTH (Salesse et al., 1978). 17a20 $\beta \mathrm{P}$ and 11-KT present in the serum were measured by RIA according to Fostier et al. (1981 and 1982 respectively). Sperm motility was periodically checked after dilution in fresh water on a few males during the period of spermiation.

In one experiment carried out on 24 March 1983 the changes of pituitary and blood GTH were measured in groups of five individuals sampled during a $24 \mathrm{~h}$ period at $06.00,10.30$, $18.00,24.00$ and 06.00 hours.

A fragment $(1 \mathrm{~cm})$ of each gonad was taken for conventional histological procedure (staining with eosin and haematoxylin), and stages of gonad maturity were determined as follows (see Table I):

Stage 1: immature stage, the testes are filiform, only primary germ cells and A-type spermatogonia (GA) are present.

Stage 2: initiation of spermatogenesis, characterized by strong mitotic activity and the presence of B-type spermatogonia (GB) in large numbers in all parts of the testis; some primary and secondary spermatocytes are present.

Stage 3: active spermatogenesis, characterized by a large number of GB, spermatocytes and spermatids in all parts of the testis. There is an increased amount of spermatozoa compared to the previous stage.

Stage 4: accumulation of spermatozoa, GB spermatocytes and spermatids are still present and located at the periphery of the testes. The spermatids are present in large numbers but relatively less than in the previous stage.

Stage 5: spermiation, the same cells as in stage 4 with spermiation (production of milt following abdominal pressure).

\section{RESULTS}

\section{GONAD DEVELOPMENT}

During the sampling period the fish grew from $132 \mathrm{~g}$ in October 1981 to $857 \mathrm{~g}$ in March 1985 (Table II). The weight of the viscera (gonad excluded, expressed in \% body weight) remained stable during the entire period. All fish were still immature on 24 March 1982 at 10 months of age; average body weight was $73.9 \mathrm{~g}$ (Table II) 


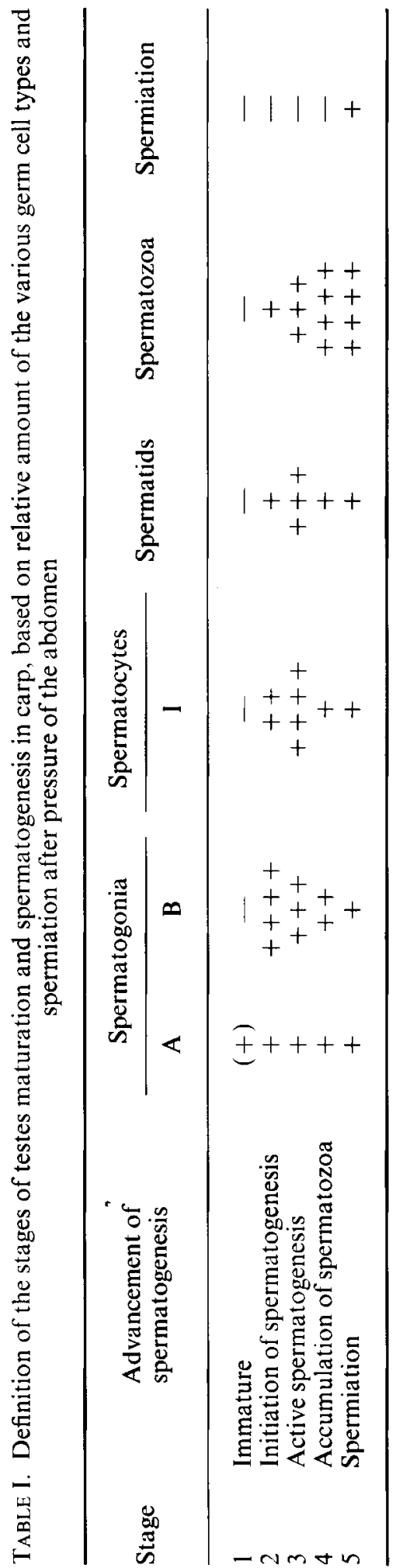




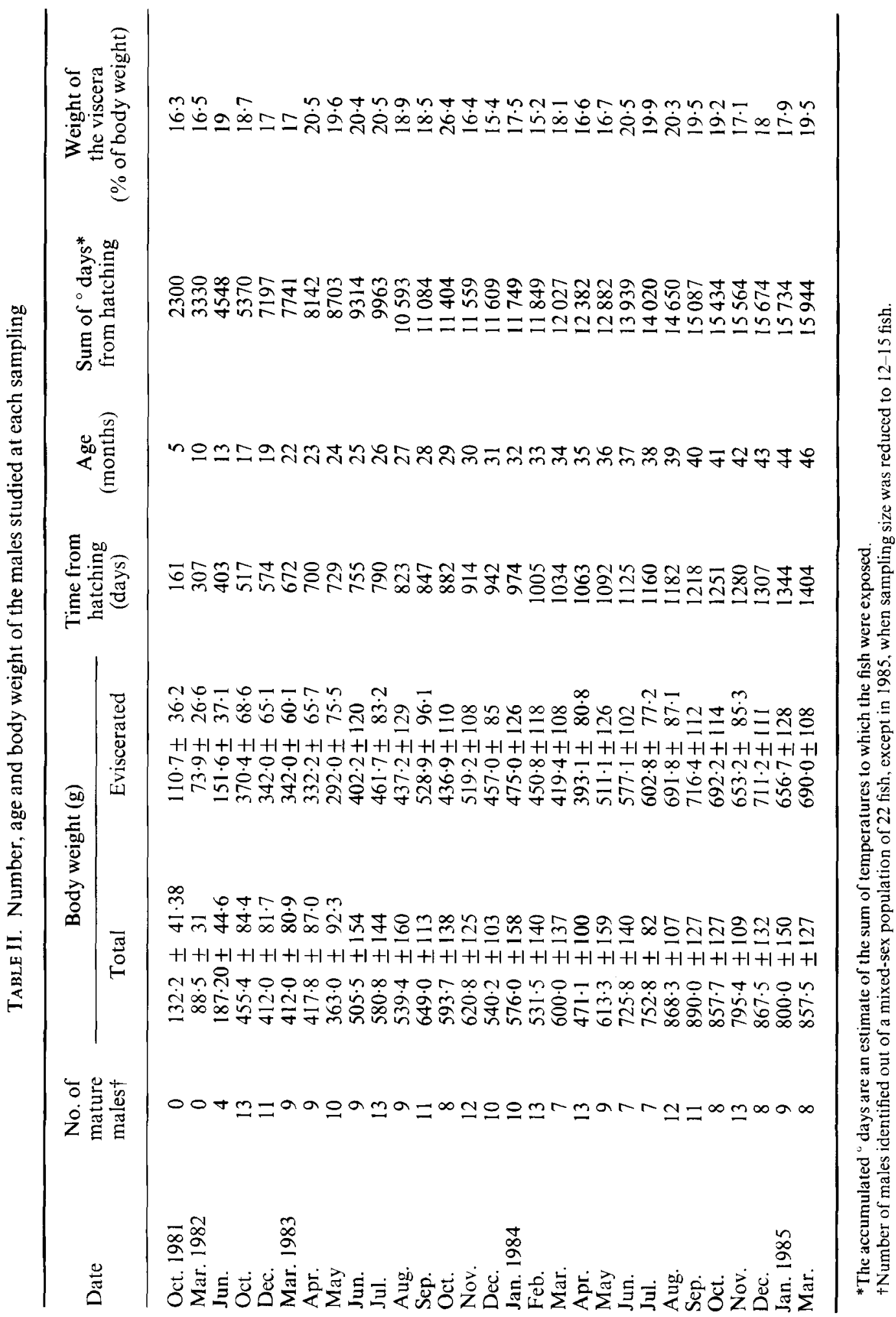



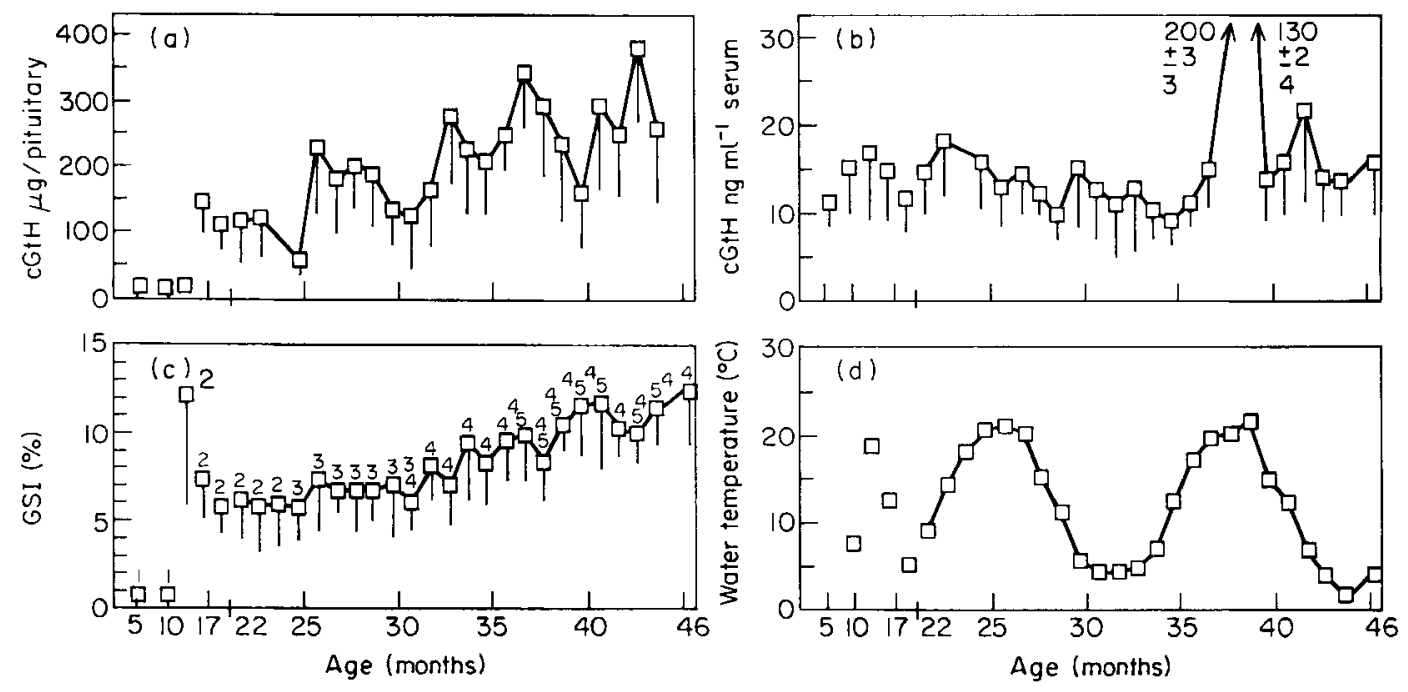

$\begin{array}{ccccccc}\text { Sompling Oct. Oct. } & \text { Jun. } & \text { Nov. } & \text { Apr. } & \text { Sep. } & \text { Mar. } \\ \text { dates: } 1981 & 1982 & 1983 & 1983 & 1984 & 1984 & 1985\end{array}$

Oct. Oct. Jun. Nov. Apr. Sep. Mar. $1981 \quad 1982 \quad 1983 \quad 1983 \quad 1984 \quad 1984 \quad 1985$

FIG. 1. Changes in some parameters measured in male carp for a period of 4 years post-hatching (fish were immature in October 1981 and March 1982 at 5 and 10 months of age, and males were mature for the rest of the time). (a) Total c-GTH content in the pituitary. (b) c-GTH concentration in bloodstream. (c) GSI. (d) Water temperature: daily average temperature from the previous sampling (the cumulative number of " days is given in Table II). From 5-22 months sampling was at 3-6 month intervals; from 22 to 44 months sampling was every month. Average values are given with S.D. The stages of testes development (Table I) are given above the GSI average values; in some cases males were found at different stages in the same sampling.

and the sex of the gonad could not be identified visually. Three months later, four males out of 22 fish sampled showed large testes, three of them having a GSI of $15 \%$ and the other of $4 \%$ (Fig. 1). In these males histological examination showed that spermatogenesis had started (stage 2) with a large proliferation of GB, some meiotic spermatocytes and a few spermatids and spermatozoa, already released in the lumen of the lobules. In the other fish the gonads were still at an immature stage.

In October 1982, at 17 months of age, all fish could be sexed from the appearance of the gonads and all males were maturing with a mean GSI of $7 \cdot 17 \%$ (Fig. 1). During the following months the GSI decreased, stabilized around $6 \%$, and the maturing (stage 2) testes remained at stage 2 with a dominance of GB until April 1983. At the normal time of carp reproduction in Poland (May-June) spermatogenesis had progressed slightly and the testes reached maturity stage 3 : spermatogenesis was still active and there was a large accumulation of spermatozoa but no spermiation although the temperature was high (average $>20^{\circ} \mathrm{C}$ in June).

The 1984 and 1985 samples showed a regular and slow increase of the GSI, reaching $13 \%$ for 4-year-old males. During this development there was a progressive shift of the maturity stage which was 3 until the end of 1983 (30 months); it reached 4 from December 1983 to June 1984 ( 37 months) and was 4-5 during the rest of the sampling period. Spermiation (stage 5) was then first observed in June 1984 , i.e. at 3 years of age although active spermatogenesis was seen 2 years earlier. Spermiation was identified in most of the males not only during the normal reproductive season but continued into the following autumn, winter and spring in 
nearly all males sampled even when the temperature was near $0^{\circ} \mathrm{C}$. When checked spermatozoa were motile.

\section{GONADOTROPIN}

The gonadotropin component was characterized by a relatively high level of GTH in the blood ( $\geq 10 \mathrm{ng} \mathrm{ml}^{-1}$ ) during the two first samples at 5 and 10 months of age, while there was no testes development and nearly no GTH stores in the pituitaries (Fig. 1). When the first maturing males were detected at the age of 6 months in June 1982, the plasma GTH was unexpectedly in the same range in the four mature males $\left(\bar{x}=13 \cdot 2 \mathrm{ng} \mathrm{ml}^{-1}\right)$ and in the 18 immatures (males and females) fish $\left(\bar{x}=16 \mathrm{ng} \mathrm{ml}^{-1}\right)$. In contrast, the GTH pituitary content was slightly lower in the mature males $(2.03 \mu \mathrm{g}$ pituitary) than in the immature fish $(4.8 \mu \mathrm{g} /$ pituitary) $(P<0 \cdot 05)$. The pituitary and plasma GTH contents were in the same range in the males with high ( $15 \%, n=3$ males) and low ( $4 \cdot 1 \%, n=4$ males) GSI.

From 19 to 37 months of age males showed testis development and a relatively stable mean level of GTH in the blood fluctuating from 10 to $20 \mathrm{ng} \mathrm{ml}^{-1}$ plasma. At 38 and 39 months of age they showed a sudden enormous and rather homogeneous surge of GTH (200 and $130 \mathrm{ng} \mathrm{m}^{-1}$ respectively). GTH returned to the June level in September-October and remained there until March 1985 with the exception of a slight rise reaching $20 \mathrm{ng} \mathrm{ml}^{-1}$ in November 1984. In the pituitary, the GTH showed some fluctuations of the mean values and high individual variability with a general tendency to rise with the age of the fish.

\section{TESTOSTERONE AND PROGESTAGEN}

Concerning steroid variation in the blood, we observed a four- to five-fold increase of 11-KT at 23-25 months in April and June 1983, and at 36-37 months, when compared to the previous months (Fig. 2) In April and June 1983, and in May 1984, all fish sampled were at the same stages of gonad development 2, 3 and 4 respectively, at the ages of 23,25 and 36 months. At 36 months, one out of seven fish was at stage 5 , the remaining six being at stage 4 . A significant $(P<0.02)$ increase in $17 a 20 \beta \mathrm{P}$ (four- to five-fold) was observed after the 11-KT surge: it occurred at the ages of 28-30 months and 38-39 months $(P<0.05)$ (Fig. 3). The gonads were then all at stages 3 and 4 respectively, for all the fish except for 1 at 38 months (stage 5). The high variability of the $17 a 20 \beta \mathrm{P}$ due to high individual values in some males (up to $2.5 \mathrm{ng} \mathrm{ml}^{-1}$ ) may be related to early stages of spermiation.

\section{GnRH}

Measurements of s-GnRH carried out from 35 to 46 months of age indicated high pituitary contents between 35 and 42 months (Fig. 4). This rise was biphasic with maximum values around $6 \mathrm{ng}$ GnRH pituitary in months 37-38 (which coincided with high levels of GTH in the blood) and in months 42-43. A drop to $2 \mathrm{ng}$ was also observed in month 39 . The rest of the time the level remained at less than $0.5 \mathrm{ng} /$ pituitary. The GnRH content in pituitary glands was always higher in males at stage 4 than at stage 5 . In the hypothalamus GnRH was low from 38 to 43 months with a peak at 42 months (November) (Fig. 5). During this period the GnRH level was high in the pituitary. The GnRH in the hypothalamus increased sharply in January 1985 (month 44) when in the pituitary it dropped to its minimum value. 


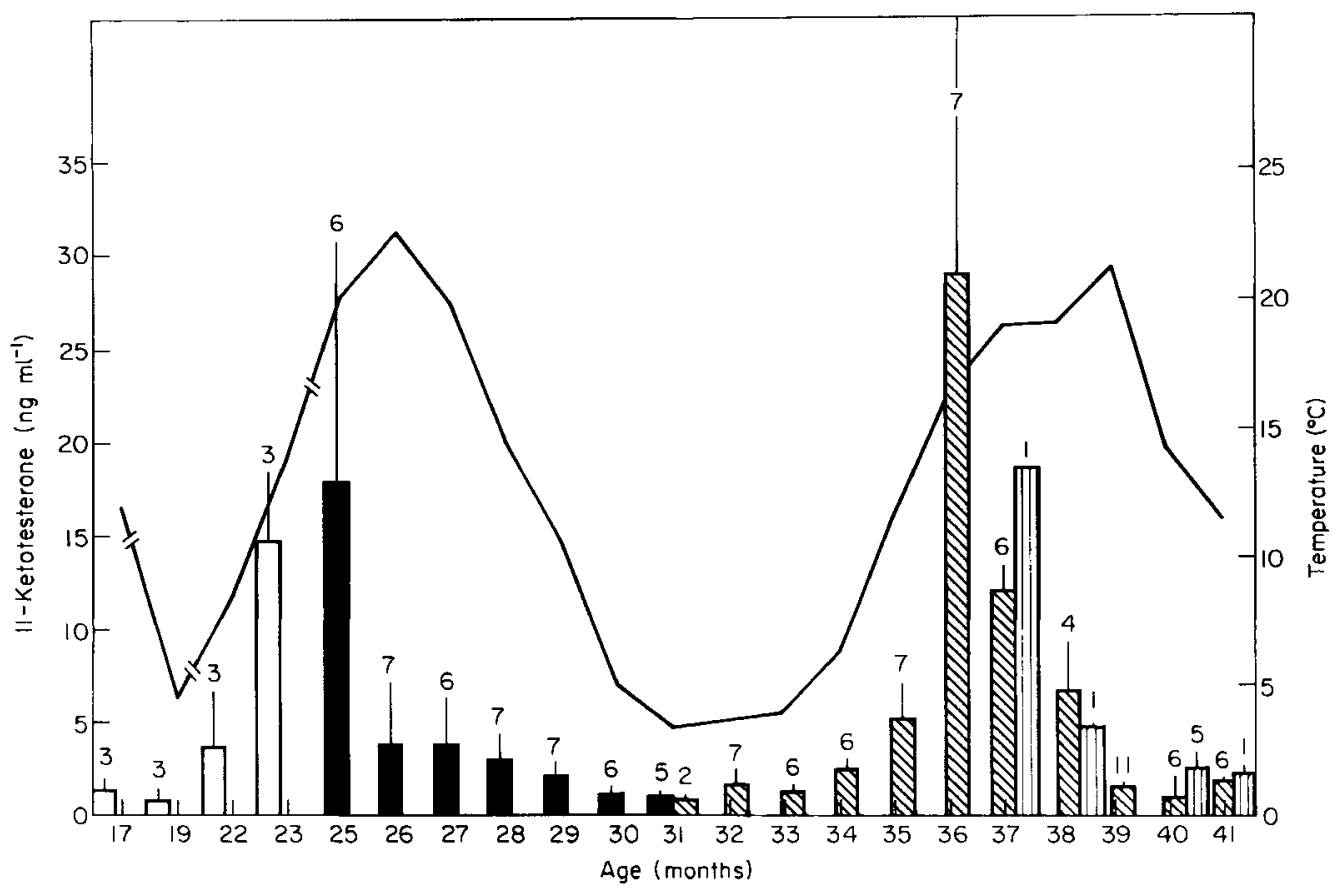

Oct. Dec. Mar. Apr. Jun. Jul. Aug, Sep. Oct. Nov. Dec. Jan. Feb. Mar. Apr. May Jun. Jul. Aug. Sep. Oct.

FIG. 2. Changes in blood 11-ketotesterone during growth and sexual maturation of male carp. Values are mean and S.D. Numbers above bars are the numbers of specimens. Maturity stages: $\square, 2 ; \mathbf{\square}, 3 ; \mathbb{N}, 4$; III, 5. Trace average daily temperature for the previous month.

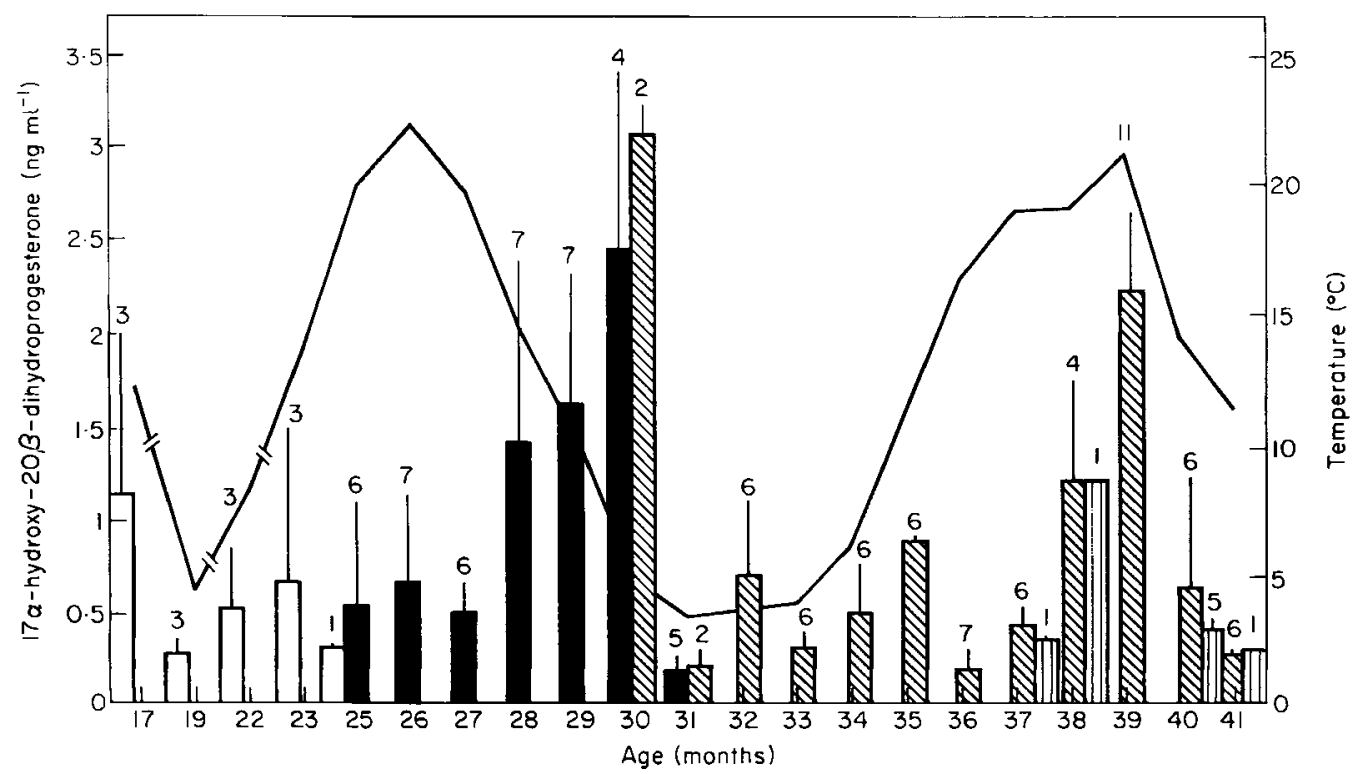

Oct. Dec. Mar. Apr. Jun. Jul. Aug. Sep. Oct. Nov. Dec. Jan. Feb. Mar. Apr. May Jun. Jul. Aug. Sep. Oct.

FIG. 3. Changes in blood 17a-hydroxy-20 $\beta$-dihydroprogesterone during growth and sexual maturation of male carp. Values are mean and S.D. (for explanation see caption to Fig. 2). 


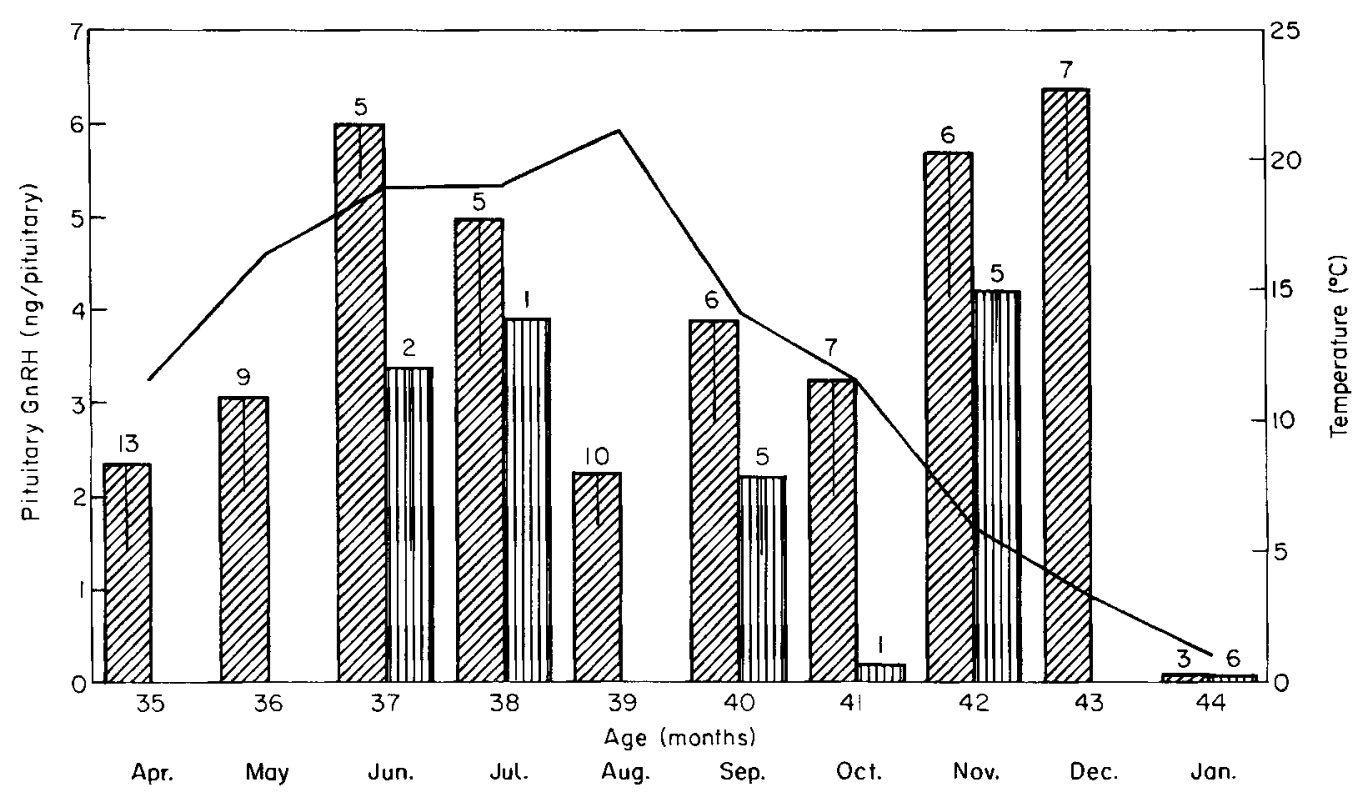

FIG. 4. Changes in pituitary GnRH (reference to s-GnRH) during growth and sexual maturation in male carp. Values are mean and S.D. (for explanation see caption to Fig. 2).

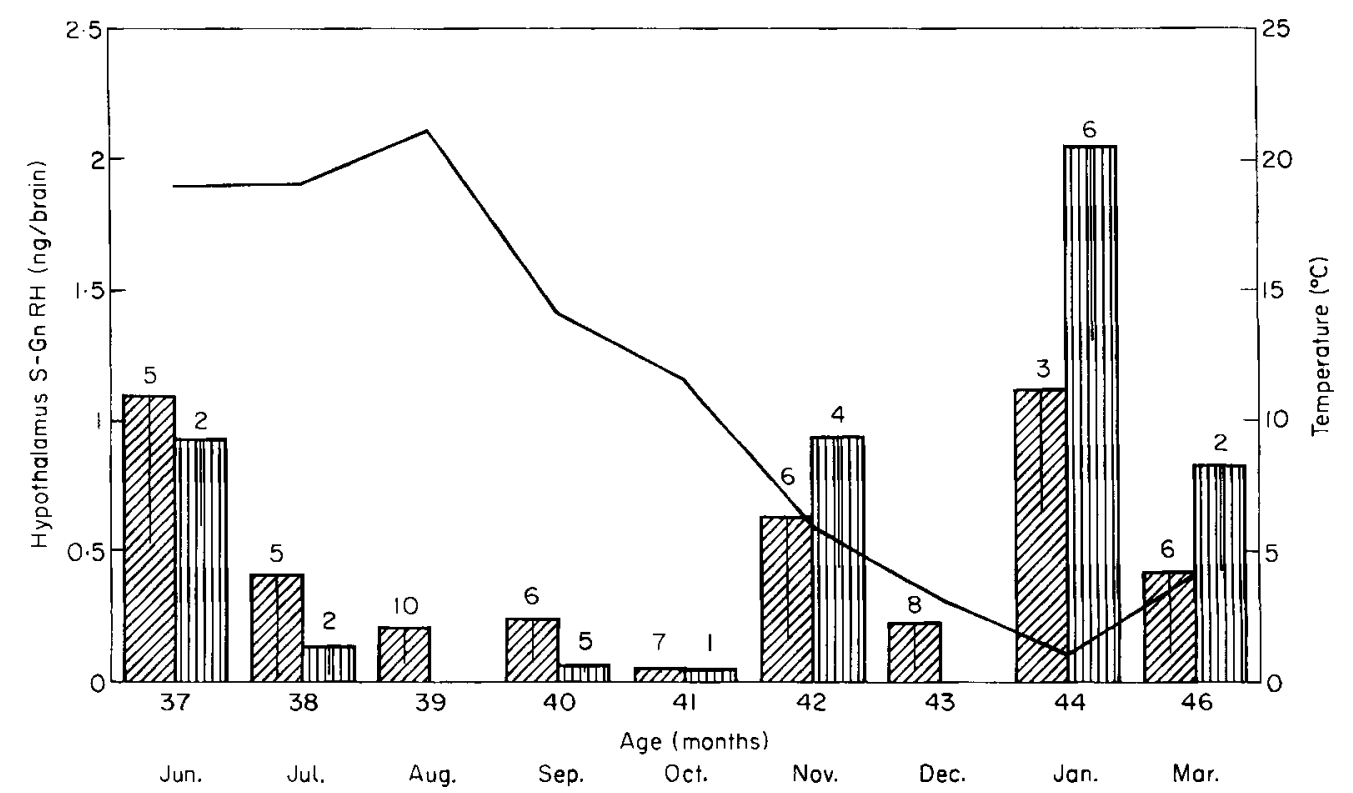

FIG. 5. Changes in hypothalamus s-GnRH in malc carp. Values are mean and S.D. (for explanation see caption to Fig. 2). 


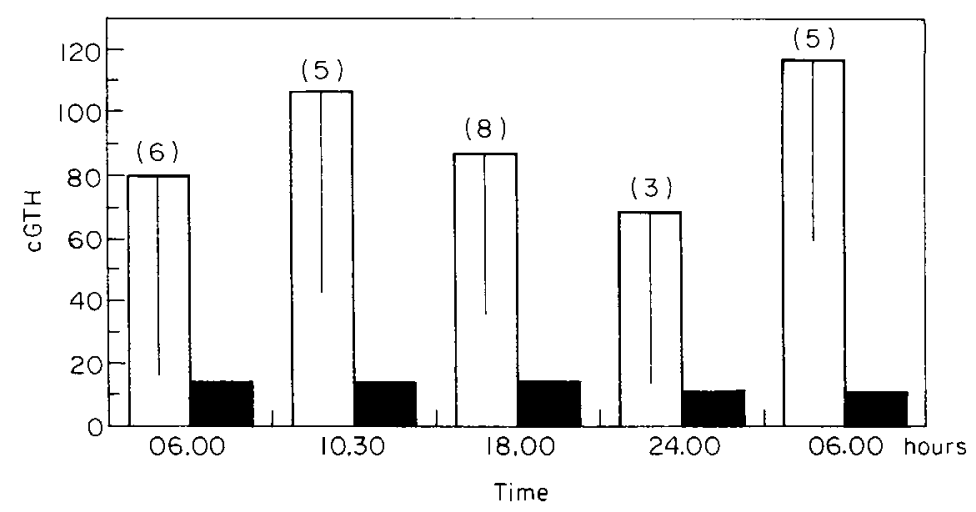

FIG. 6. Changes in pituitary ( $\square)$ and blood ( $\square)$ c-GTH $(x \pm$ S.D. $)$ in 22-month-old mature male carp during a $24 \mathrm{~h}$ period (24-25 March 1983); GTH is expressed in $\mu \mathrm{g} \mathrm{ml}^{-1}$ serum and $\mathrm{ng} /$ pituitary. The number of males sampled is given in parentheses.

The GTH serum level did not vary at all during a $24 \mathrm{~h}$ period (Fig. 6), whereas the GTH pituitary content did not change significantly, with a minimum value of $67 \mu \mathrm{g}$ pituitary at 24.00 hours and a maximum value $117.6 \mu \mathrm{g}$ pituitary at 06.00 hours.

\section{DISCUSSION}

All males remained immature and no gonad development occurred until 10 months of age in March (i.e. after $3330^{\circ}$ days) although there were significant amounts of GTH in the blood circulation. During this period there was no major store of GTH in the pituitary and maturing gonadotropin was obviously secreted into the blood without effect on the testis, probably due to the unresponsiveness of this organ. At 13 months of age ( $4548^{\circ}$ days) testes were already developed, indicating that puberty was established. Under more favourable climatic conditions, puberty may occur as early as 6 months in Israel (Rothbard \& Rothbard, 1982) and in South East Asia (Bieniarz, 1986). Among 327 fish in the South of France (Camargue), Crivelli (1981) found that $26 \%$ of the males were mature in their first year, and $94 \%$ in their second.

At least in some males there was an explosive development of the testes between 10 and 13 months, with a huge multiplication of $B$ type spermatogonia ending with an enormous GSI value (15\% for three males out of four found maturing). Such values are not usually reported in young or even adult male carp, suggesting that the regulation of the size of the testis was not yet fully established. It should be pointed out that these males with high GSI were small in size (average $187 \mathrm{~g}$ ) which might account for the high GSI. In males taken later the testis was smaller but the stage of spermatogenesis remained unchanged (until 25 months in June 1983) indicating that there was no progression of spermatogenesis. Such an interruption may be due to the low temperature in winter and spring. However, considering the stage of testis development in autumn, and previous reports by Solewski (1957), Weil (1981) and Saad \& Billard (1987) showing that spermiation occurred at 2 years of age, full spermatogenesis and spermiation should have been expected 
in this summer. In fact stage 3 (corresponding to a rather advanced stage of spermatogenesis) was observed in July but no spermiation was noticed in that year although $11-\mathrm{KT}$ and $17 a 20 \beta \mathrm{P}$ were found in the blood. Possibly spermiation was discrete and not detected, considering that in captivity male spermiation is very limited and that stimulation is necessary with LHRH or LHRH.A (Billard et al., 1983a, b, 1987; Takashima et al., 1984) or with gonadotropin (Courtois et al., 1986; Saad \& Billard, 1987). Indeed, in all these experiments it was noticed that some males, although fully mature, did not give milt at $t_{0}$ (before injection), and were in full spermiation after hormonal treatment. Usually some spermiation was observed when the GTH concentration in the plasma was in the range of 10 $20 \mathrm{ng} \mathrm{ml}^{-1}$; such values were recorded in the present experiment in June-July 1983 when no spermiation was observed. A kind of blockage probably occurred. Stressful conditions may have resulted through high fish density $\left(2000 \mathrm{~kg} \mathrm{ha}^{-1}\right)$ and an insufficient feeding rate (indicated by the slow growth rate, and the same weight of viscera in summer and in winter) leading to a relatively low growth rate especially during the third year ( $363 \mathrm{~g}$ at 2 years, $471-613 \mathrm{~g}$ at 3 years and $857 \mathrm{~g}$ at 4 years of age, Table II).

The question of social interaction between sexes may also be taken into account. In 1983 the nearly mature, non-spermiating, males were mixed with females which were still immature (see Bieniarz et al., 1991). As it was shown that spermiation was stimulated by ovulating females in goldfish Carassius auratus L. (Stacey et al., 1987) and in carp (Billard et al., 1989), the lack of spermiation observed here may be due to the absence of mature females in the pond. However, in the following year, 1984 some of the 3-year-old males were spermiating but the females were not yet fully mature (Bieniarz et al., 1991). It is possible that the presence of females in a mixed age carp population is necessary, both in ponds and in nature, for the achievement of full spermatogenesis and spermiation at 2 years of age.

Significant and high levels of 11-KT were observed between April-June and May-June in two consecutive years (age 2 and 3 years) and coincided with the rise of water temperature, but this cannot be related to a clear-cut event in the gonad. A rise of $11-\mathrm{KT}$ was observed in males at any spermatogenetic stage 2, 3, 4 and 5. 11-KT has already been reported as being the major androgen in male carp (Weil et al., 1986) and is closely associated with reproduction in males (Kime \& Manning, 1986), including spermiation (Weil et al., 1986; Takashima et al., 1984; Barry et al., 1990a). However, Weil (1981) did not find major changes in the level of total androgens in mature male carp during a 1-year study; the average level remained below $4 \mathrm{ng} \mathrm{ml}^{-1}$ plasma which corresponds to the basal level of $11-\mathrm{KT}$ observed in this study.

The coincidence between the rise in the circulating androgens and the increase of temperature observed here and reported in various experiments (Okuzawa et al., 1989; Barry et al., 1990a) suggests that temperature change plays a role in the regulation of androgen secretion. The circulating level of $17 a 20 \beta \mathrm{P}$ also changed during the study but to a lesser extent and with more fluctuations than in 11-KT. Levels above $1 \mathrm{ng} \mathrm{ml}^{-1}$ were observed in males at any spermatogenetic stage (2, 3, 4 and 5) and changes occurred independently of annual temperature fluctuations. However the 11-KT-17a20 $\mathrm{P}$ peak sequence observed in a $24-\mathrm{h}$ period in carp and other cyprinids, white sucker, Catostomus commersoni Lacepède (Scott et al., 1984) and goldfish (Kobayashi et al., 1986) cannot be identified here from monthly 
samplings. As there was no change in $17 a 20 \beta \mathrm{P}$ when spermiation was observed, carp seems different to trout Salmo trutta L., in which involvement of $17 a 20 \beta \mathrm{P}$ has been suggested in the process of spermiation, but no conclusion can be drawn from these monthly observations. It should be pointed out that Saad \& Billard (1987) could not stimulate spermiation in carp after injection of $17 a 20 \beta \mathrm{P}$. However this progestagen may be involved in other functions, such as the 'maturation' of spermatozoa, as Barry et al. (1990b) showed that a shift in the steroidogenic pathway from androgen to progestagen production was regulated by spermatozoa.

The level of GTH in the blood circulation did not vary much during the sampling period with the exception of a huge rise in July and August 1984 at the age of 38-39 months which coincided with a rise in temperature and the appearance of fish at stage 5. The rest of the time it fluctuated between 10 and $15 \mathrm{ng} \mathrm{m}^{-1}$ which is slightly higher than other data reported: $5 \mathrm{ng} \mathrm{ml}^{-1}$ plasma for Breton et al. (1975), and less than $5 \mathrm{ng} \mathrm{ml}^{-1}$ plasma for Weil (1981). In pre-spermiating males the basal level reported was as $13-15 \mathrm{ng} \mathrm{ml}^{-1}$ plasma by Saad \& Billard (1987), around $4 \mathrm{ng}$ by Billard et al. (1978), $1 \mathrm{ng}$ by Takashima et al. (1984), I to $3 \mathrm{ng}$ by Billard $e t$ al. (1983a) and by Lin et al. (1986).

The GTH content in the pituitary progressively increased with the age of the fish. This was probably due to the mode of expression per pituitary, whose size also increased with age. In March 1983 (22 months) there was no major change in the blood and pituitary GTH content during a 24 -h period. This suggests that the values from point sampling may be a good estimate of development with time over the months, and that the rise in July and August 1984 at the age of 37-38 months was not due to a change in a nycthemeral pattern. However no nycthemeral rhythm of synthesis or secretion during 1 day in March 1983 does not prove that it did not exist for the rest of the time.

The GnRH contents measured monthly in 1984 and 1985 (months 35 and 46) appeared to vary in opposite ways in the brain and in the pituitary (Figs 4 and 5). High levels in the pituitary between June and December 1984 (months 37 and 43) corresponded to low levels in the brain. After December 1984, GnRH was high in the brain and low in the pituitary. The high rise in plasma GTH observed in JulyAugust 1984 (months 38-39) coincided with a high level of GnRH in the pituitary in June-July. The biological significance of coincident changes of brain and pituitary GnRH and blood GTH is not clear, except that the rise of GnRH in the pituitary occurred with the large rise of blood GTH and the beginning of spermiation. During the previous year when there was no spermiation, no rise of pituitary GnRH was observed. No data are available on GnRH changes during spermatogenesis of other fish species. However in females GnRH increased in the pituitary in ovulating or freshly ovulated brown trout, compared with females in the final stage of gonadal maturation (Breton et al., 1986). Yu et al. (1987) did not find clear parallel changes in brain GnRH with ovarian development in goldfish, but at $10^{\circ} \mathrm{C}$ the hypothalamus and pituitary content decreased as the gonad matured.

This work confirms previous studies by Weil (1981), who showed that the process of spermatogenesis in carp is characterized by the presence of all types of germ cells all year round; only subtle changes in the ratio of the various cell types may be observed throughout the year. A well-defined stage of initiation of spermatogenesis, with high mitotic activity occurs only in mature fish undertaking the first 
reproductive cycle and is never identified in fish in later cycles. In these fish there is a large accumulation of spermatozoa in the testes, possibly due to the absence of release since the males were not stripped and were not involved in reproduction. Therefore the relative number of B-type spermatogonia, spermatocytes and spermatids decreased and stage 4 became the stage permanently recorded. However the permanence of all types of germ cells does not mean that spermatogenesis is active all the time. It is not possible in these conditions to define clearly, from simple histological examination, the seasonality of spermatogenesis, and no phenomenon of testicular recrudescence (Grier \& Abraham, 1983) can be identified. The seasonality of spermatogenesis cannot be established in the present work from the change in GSI, since it remains at the same level during 2 years following the initiation of spermatogenesis in March 1982. The regular increase in testis weight observed from 1984 and 1985 probably just reflects the accumulation of spermatozoa in the testes which is the only evidence of some spermatogenetic activity.

However in the same climatic conditions, Solewski (1957) showed a more classic development in carp, with a progressive elevation of GSI during the second year of age reaching $5 \%$ in May and declining during the reproductive season to $3 \cdot 2 \%$ in September. The same type of development occurred during the second cycle, with a GSI going from $3.3 \%$ in October to $7.7 \%$ in June before declining to $5 \%$ in August. Crivelli (1981) showed seasonal changes in the testis weight of carp in the south of France; a rise of GSI from $4.5 \%$ in August to $8 \%$ in March and a decline to $4.5 \%$ in July. Some seasonality could then be identified from the testes growth in autumn and winter. Weil (1981) found a rise in testes weight in summer.

The situation in male carp appears very different to some species, in which the seasonality of the spermatogenetic activity is much more obvious, with a clear cut change in germ cell assemblages and their succession, and with a quasi-entire elimination, at the end of the reproductive season, of the spermatozoa produced during the spermatogenetic cycle. This elimination occurs by spontaneous release or resorption in the testis or in the spermduct of the spermatozoa. Concomitantly the GSI decreases to nearly 0 after the reproductive season and before a new cycle starts. This was observed in some salmonids (Billard et al., 1978; Billard, 1983, 1987), in pike, Esox lucius L. (Billard et al., 1983c), and in sea bass Dicentrarchus labrax L. (Zohar et al., 1984). This point is discussed in more detail in Billard et al. (1978).

One of the consequences of the sperm not being released in carp is that spermatozoa accumulate in the testis over the years, and may age and decline in quality. This was suggested in the case of sperm preservation, both in the short term in the liquid state (Saad et al., 1988) and cryopreservation (Cognie et al., 1989). Another consequence of the accumulation of spermatozoa in the testes may be a limitation of space for other cell types and a reduction in the efficiency of spermatogenesis; this efficiency seemed very high at the beginning of the first cycle, considering the high GSI due to a considerable multiplication of B-type spermatogonia, whose number was never as high in the subsequent cycles.

This work was supported initially by an INRA international grant to RB, and a PR4 grant to KB. The completion of the paper was carried out under a grant by the Ministry of Research and Technology in France. Thanks are due to Dr A. Fostier for help with the steroid assay and J. Barthelemy for typing the manuscript. 


\section{References}

Barry, T., Santos, A. J. G., Furukawa, K. A., Katsumi \& Hanyu, I. (1990a). Steroid profiles during spawning in male common carp. General Comparative Endocrinology 80, $223-231$.

Barry, T., Asahima, K., Aida, K. \& Hanyu, I.(1990b). The mechanism regulating the shift from androgen to progestagen production during spawning in male common carp Cyprinus carpio: a review. In The Second Asian Fisheries Forum (Hirano, R. \& Hanyu, I., eds), pp. 603-606. Manila: Asian Fisheries Society.

Bieniarz K.(1986). Sex differentiation and puberty in cyprinids. In Aquaculture of Cyprinids (Billard, R. \& Marcel, J., eds), pp. 101-108. Paris: INRA.

Bieniarz, K., Weil, C., Epler, P., Mikolajcayk, T., Breton, B., Bougoussa, M. \& Billard, R. (1991). Gonadotropin hormone and gonadotropin releasing hormone changes during growth and sexual maturation of female carp. Polish Archives of Hydrobiology in press.

Billard, R. (1983). A quantitative analysis of spermatogenesis in the trout, Salmo trutta fario. Cell Tissue Research 230, 495-502.

Billard, R. (1987). The reproductive cycle of male and female brown trout Salmo trutta fario: a quantitative study. Reproduction Nutrition Dévelopment 27, 29-44.

Billard, R., Breton, B., Fostier, A., Jalabert, B. \& Weil, C. (1978). Endocrine control of the teleost reproductive cycle and its relation to external factors: salmonid and cyprinid models. Comparative Endocrinology, pp. 37-48. Amsterdam: Elsevier.

Billard, R., Alagarswami, K., Peter, E. \& Breton, B. (1983a). Potentialisation par le pimozide des effects du LHRH-A sur la sécrétion gonadotropine hypophysaire, l'ovulation et la spermiation chez la carpe commune Cyprinus carpio. Comptes Rendus de l'Académie des Sciences, Paris série D 296, 181-184.

Billard, R., Choisis, J. P. \& Reinaud, P. (1983b). Stimulation of spermiation in carp in response to LH-RH and D-Ala6-LH-RH ethylamide. Aquaculture 35, 173-176.

Billard, R., Mackay, W. C. \& Marcel, J. (1983c). Evolution de la gamétogenèse, du poids du corps et des gonades au cours du cycle reproducteur du brochet Esox lucius. In Le Brochet: Gestion dans le Milieu Naturel et Élevage (Billard, R., ed.), pp. 53-61. Paris: INRA.

Billard, R., Bieniarz, K., Popek, W., Epler, P., Breton, B. \& Alagarswami, K. (1987). Stimulation of gonadotropin secretion and spermiation in carp by pimozide-LRH-A treatment: effects of dose and time of day. Aquaculture 62, 161-170.

Billard, R., Bieniarz, K., Popek, W., Epler, P. \& Saad, A. (1989). Observations on a possible pheromonal stimulation of milt production in carp Cyprinus carpio L. Aquaculture 77, 387392.

Breton, B., Kann, G., Burzawa-Gerard, E. \& Billard, R. (1971). Dosage radioimunologique d'une hormone gonadotrope de carpe Cyprinus carpio. Comptes Rendus de l'Académie des Sciences, Paris Série D. 272, 1515-1517.

Breton, B., Jalabert, B. \& Fostier, A. (1975). Induction de decharges gonadotropes hypophysaires chez la carpe Cyprinus carpio L. à l'aide du citrate de cisclomiphène. General and Comparative Endorinology 25, 400-404.

Breton, B., Motin, A., Billard, R., Kah, O., Geoffre, S. \& Precigoux, G. (1986). Immunoreactive gonadotropin releasing hormone-like material in the brain and the pituitary gland during the periovulatory period in the brown trout Salmo trutta L. Relationship with the plasma and pituitary gonadotropin. General and Comparative Endocrinology 61, 109-119.

Cognie, F., Billard, R. \& Chao, N. H. (1989). La cryoconservation de la laitance de carpe Cyprinus carpio. Journal of Applied Ichthyology 5, 165-176.

Courtois, F., Takashima, F. \& Billard, R. (1986). Stimulation of spermiation following repeated injection of carp pituitary homogenates in the carp. Bulletin of the Japanese Society of Scientific Fisheries 52, 995-997.

Crivelli, A. J. (1981). The biology of the common carp, Cyprinus carpio L. in the Camargue, Southern France. Journal of Fish Biology 18, 271-290.

Fostier, A., Jalabert, B., Campbell, C., Terqui, M. \& Breton, B. (1981). Cinétique de libération in vitro de 17a-hydroxy-20 $\beta$-dihydroprogesterone par des follicules de 
truite arc-en-ciel Salmo gairdneri. Comptes Rendus de l'Académie des Sciences, Paris serie $D$ 292, 777-780.

Fostier, A., Billard, R., Breton, B., Legendre \& Marlot, S. (1982). Plasma 11-oxo-testerone and gonadotropin during the beginning of spermiation in rainbow trout, Salmo gairdneri. General and Comparative Endocrinology 46, 428-434.

Grier, H. J. \& Abraham, M. (1983). A model for testicular recrudescence in Oreochromis aureus. In International Symposium on Tilapia in Aquaculture (Fishelson, L. \& Yaron, Z., eds), pp. 200-209. Tel Aviv: Tel Aviv University.

Horvath, L. (1986). Carp oogenesis and the environment. In Aquaculture of Cyprinids (Billard, R. \& Marcel, J., eds), pp. 109-117. Paris: INRA.

Kime, D. E. \& Manning, N. J. (1986). Maturational and temperature effects on steroid hormone production by testes of the carp Cyprinus carpio. In Aquaculture of Cyprinids (Billard, R. \& Marcel, J., eds), p. 168. Paris: INRA.

Kobayashi, M., Aida, K. \& Hanyu, I. (1986). Gonadotropin surge during spawning in male goldfish. General and Comparative Endocrinology 62, 70-79.

Lin, H. R., Kraak, G. V. D., Liang, J. Y., Peng, C., Li, G. Y., Lu, L. Z., Zhou, X. J., Chang, M. L. \& Peter, R. E. (1986). The effects of LHRH analogue and drugs which block the effects of dopamine on gonadotropin secretion and ovulation in fish cultured in China. In Aquaculture of Cyprinids (Billard, R. \& Marcel, J., eds), pp. 139-150. Paris: INRA.

Okuzawa, K., Furukawa, K., Katsumi, A. \& Hanyu, I. (1989). Effects of photoperiod on gonadal maturation, and plasma steroid and gonadotropin levels in cyprinid fish, the honmoroko Gonathopogon caerulescens. General and Comparative Endocrinology $75,139-147$.

Rothbard, S. \& Rothbard, H. (1982). Spermiation response of carp to homologous pituitary gland. In Reproductive Physiology of Fish (Richter, C. J. J. \& Goos, H. J. Th., eds), p. 201. Wageningen: PUDOC.

Saad, A. \& Billard, R. (1987). Spermatozoa production and volume of semen collected after hormonal stimulation in the carp, Cyprinus carpio. Aquaculture 65, 67-77.

Saad, A., Billard, R., Theron, M. C. \& Hollebecq, M. G. (1988). Short-term preservation of carp Cyprinus carpio semen. Aquaculture 71, 133-150.

Salesse, R., Garnier, J. \& Breton, B. (1978). Interaction of salmon gonadotropin sub-units; spectroscopic studies. Annales de Biologie Animale Biochimie Biophysique 18, 767-771.

Scott, A. P. MacKenzie, D. S. \& Stacey, N. E. (1984). Endocrine changes during natural spawning in the white sucker, Catostomus commersoni. III. Steroid hormones. General and Comparative Endocrinology 56, 349-359.

Solewski, W. (1957). Rozwoj gruczolow pliciowych u karpia Cyprinus carpio L. w ciagu ierwszych trzech lat zycia Odbitka Biuletynu zaktadu biologii stavov. Polskyi Akademii Nauk Krakow 4, 3-24.

Solewski, W. (1958). Obserwacje nad rozwojem i dojrzewaniem gonad u karpia Cyprinus carpio L. W czwartym roku zycia Odbitka Biuletynu zakladu biologii stavov. Polskyi Akademii Nauk Krakow 6, 35-56.

Stacey, N. E., Sorensen, P. W., Dulka, J. G., Van der Kraak, G. L. \& Hara, T. J. (1987). Teleost sex pheromones: Recent studies on identity and function. In Reproductive Physiology of Fish (Idler, D. R., Crim, L. W. \& Walsh, J. M., eds), pp. 150-153. St John's Newfoundland, Canada: Memorial University Press.

Takashima, T., Weil, C., Billard, R., Crim, W. \& Fostier, A. (1984). Stimulation of spermiation by LHRH analogue in carp. Bulletin of the Japanese Society of Scientific Fisheries 50, 1323-1329.

Weil, C. (1981). La fonction gonadotrope de l'hypophyse au cours du cycle sexuel chez deux poissons téléostéens, la carpe commune Cyprinus carpio et truite arc-en-ciel Salmo gairdneri; son controle par l'hypothalamus, les gonades et les facteurs externes. Doctoral thesis, University of Paris.

Weil, C., Fostier, A. \& Billard, R. (1986). Induced spawning (ovulation \& spermiation) in carp and related species. Aquaculture of Cyprinids (Billard, R. \& Marcel, J., eds), pp. 119-137. Paris: INRA. 
Yu, Y. L., Nahorniak, C. S., Peter, R. E., Corrigan, A., Rivier, J. E. \& Vale, W. W. (1987). Brain distribution of radioimmunoassayable gonadotropin-releasing hormone in female goldfish: seasonal variation and periovulatory changes. General and Comparative Endocrinology 67, 234-246.

Zohar, Y., Billard, R. \& Weil, C. (1984). La reproduction de la daurade Sparus aurata et du bar Dicentrarchus labrax, connaissance du cycle sexuel et contrôle de la gamétogenèse et de la ponte. In Aquaculture du Bar et des Sparidés (Barnabé, G. \& Billard, R., eds), pp. 3-24. Paris: INRA. 